\title{
The Impact of Traditional Conservation Practices on Species Composition and Diversity Patterns of Sacred Swamps in the Central Western Ghats, India
}

Narasimha Hegde ( $\square$ lifetrusts@gmail.com )

Institute of Botany and Landscape ecology, University of Greifswald University of Greifswald: Universitat Greifswald https://orcid.org/0000-0002-4640-6503

Shrikanth Vasudev Gunaga

University of Agricultural Sciences Dharwad

Hans Joosten

University of Greifswald: Universitat Greifswald

\section{Research Article}

Keywords: Composition, Diversity Patterns, Sacred Swamps

Posted Date: June 12th, 2021

DOl: https://doi.org/10.21203/rs.3.rs-591666/v1

License: (c) (i) This work is licensed under a Creative Commons Attribution 4.0 International License. Read Full License 


\section{Abstract}

Sacred forests are of immense value for their ecosystem functions. Traditional indigenous conservation practices have helped maintaining biological diversity over centuries and have resulted in the preservation of some of the best patches of natural vegetation. Exclusive taxa find refuge in the microclimatic conditions of sacred groves and many rare species are found here. Ten sacred swamps and ten non-sacred swamps in the central Western Ghats region, India, with a similar distance from roads, village settlements, or commercial orchards and with nearly the same size, were compared with regard to their species composition, floristic structure, diversity, occurrence of amphibians, odonates and birds. In the sacred swamps, 122 plant species from 99 genera and 58 families occur against 83 species from 72 genera and 47 families in the non-sacred swamps. Tree stem density was 277 individuals/ha in sacred swamps against 158.4 in non-sacred swamps. Average basal area was $47.57 \mathrm{~m} 2$ /ha in sacred swamps and only $14.60 \mathrm{~m} 2$ /ha in non-sacred swamps. Sacred swamps have higher number of endemic species (28\%) when compared to non-sacred swamps. We conclude that the traditional belief system of treating the swamps as sacred has helped to protect these ecologically important forests.

\section{Introduction}

Sacred groves play a significant role in forest stand survival across the globe (Gadgil and Chandran 1992, Tiwari et al. 1998) and are considered an effective tool in biodiversity conservation (Byers et al. 2001, Campbell 2004, Ramanujam and Kadamban 2001). They are of immense value for the ecosystem services they provide and have survived because of community-based preservation practices (Ceperly et al. 2010, Gadgil and Vartak 1976). Traditional indigenous conservation practices and values integrated with religious knowledge have helped maintaining cultural and biological diversity over centuries and have resulted in the preservation of some of the best patches of natural vegetation (Komanda et al. 2003; Gadgil and Vartak 1976). Although some supporting traditions have weakened by modern influences, sacred groves are frequently more acceptable to local peoples than externally imposed conservation policies (Ntiamoa-Baidu, 1994).

Exclusive taxa find refuge in the micro-climatic conditions of sacred groves and many rare species are found only there (Singh et al. 2011). Numerous studies suggest that the biological spectrum of sacred groves in the tropics closely resembles the typical spectrum of tropical forest biodiversity and that in sacred groves endangered and rare species of flora and fauna are better protected and conserved than elsewhere (Tiwari et al. 1998; Campbell 2004; Shahabuddin and Rao 2010, Shen et al. 2015).

Recurrent human interventions in the forests are known to change habitat fitness for many species leading to a decrease in number of species along the disturbance gradient (Pandey and Shukla 1999). While some species may tolerate disturbance, others may not and disappear (Sagar, 2003). Leigh (1965) suggests that stability increases with the complexity of the ecosystem, i.e. with the number of species and their interactions (MacArthur 1955). Heterogeneous forests may accommodate more species, particularly those requiring specialized microhabitats (Hansen et al. 1991, Pausas \& Austin 2001), 
because they provide greater variety in microclimate, hiding and nesting sites etc., compared to more homogeneous forests (e.g. McArthur and McArthur 1961, Murdoch et al. 1972). Especially the structure of the tree stratum has a central role in determining the ecological processes and habitat characteristics in the forest (Kuuluvainen et al. 1996). Structural complexity of forests is, thus, often a good predictor of overall species diversity (Begon et al. 1986) and can be used to assess the conservation or biodiversity value of forest stands (Hansen et al. 1991).

Whereas forest structure informs biodiversity, information on the latter (i.e., species composition, diversity and population structure) is essential to understand forest ecosystem dynamics at various levels (Giriraj 2008), to provide a conceptual framework and measurable indicators to assess the overall ecosystem condition, and to monitor change (Noss 1990).

Such structural richness and tree species diversity are found in the fresh water swamps of the Uttara Kannada district of the Central Western Ghats, India. Fresh water swamps are marshy areas where water flows in perennial streams at constant level throughout the year (Gupta et al. 2006). Within the climax evergreen forests, they occupy poorly drained depressions that often open into a river or rivulet and have their groundwater level very close to the ground surface. Some of these swamps are sacred. Such sacred swamps today only exist close to commercial gardens, roads and settlements (average distance 100 meters, Hegde et al. 2018).

This paper compares species composition and tree population structure in sacred and non-sacred swamps in order to explore whether the traditional belief systems of treating swamps as sacred are effective in protecting ecologically important forests.

\section{Study Area}

The Western Ghats Mountain ranges, running parallel along the west coast of India, constitute one of the eighteen 'hottest global biodiversity hotspots' of the world, because of their large number of endemic biota and the scale and speed of their current habitat loss (Myers et al. 2000). The mountain ranges support - together with Sri Lanka - about 4780 vascular plant and 1073 vertebrate species, of which, respectively, 2180 (i.e., $0.7 \%$ of the world's plant species) and 355 species (i.e., $1.3 \%$ of the global vertebrate species) are endemic. At the same time, the region has lost most of its primary vegetation with only $6.8 \%$ of the original vegetation remaining (Myers et al. 2000, Bawa et al. 2007). Uttara Kannada $\left(13.85^{\circ}-15.7166^{\circ} \mathrm{N}, 74.166^{\circ}-75.2833^{\circ} \mathrm{E}\right)$ is one of the most densely vegetated districts within the Western Ghats and is endowed with rich natural resources. Of its $10,250 \mathrm{~km}^{2}$ about $81 \%$ is still forest, and only $12 \%$ is used for agriculture.

\section{Methods}

Ten sacred swamps (total area $5.60 \mathrm{ha}$ ) and ten non sacred swamps (total area $5.71 \mathrm{ha}$ ) of similar size were studied. The sacred swamps had an average distance to the nearest road, settlement or commercial 
orchard of $109 \mathrm{~m}$ (standard deviation 19.5), the non-sacred swamps an average distance of $332 \mathrm{~m}$ (standard deviation 66.7) (Table 1).

Vegetation was assessed between December 2013 and April 2014 in transects of $5 \mathrm{~m}$ wide and variable length (100-1000 m) along the stream, covering a total area of 1.70 ha (sacred swamps) and 1.71 ha (non-sacred swamps). Since the swamps have a linear shape, almost the entire depression part of the swamps was surveyed. The species composition in the catchment area of the swamp forests was assessed in a transect of $50 \mathrm{~m} \times 5 \mathrm{~m}$ perpendicular to the edge on either side of each swamp. All plant species were identified using regional and standard floras (Cooke 1903, Talbot 1909, Gamble and Fischer 1935) and keys (Pascal and Ramesh 1987). Tree girth was measured at breast height using a measuring tape. Tree diameters were categorized in 11 diameter classes of $30 \mathrm{~cm}$, with the smallest class having 1$30 \mathrm{~cm}$ and the largest $\geq 301 \mathrm{~cm}$ diameter at breast height (DBH).

Faunal data were collected in different seasons viz., rainy (June and July 2014), winter (October and November 2014) and summer (April and May 2015). The entire area of the swamps was surveyed for amphibians, selected insect groups and birds. Amphibian species were recorded by a team of four to five people carrying out a detailed search of all possible habitats, including leaf litter, bushes and small trees for arboreal taxa. Torches were used to find and identify amphibians by following their calls at night. Dragonflies, damselflies and butterfly species were recorded through visual observation. Birds were recorded by visual observation and audio identification (by hearing the calls). Faunal documentation took three to five hours per swamp per season and per team. The study of amphibians took nearly 490 person hours of field work, that of dragonflies, damselflies, butterflies and birds in total 660 hours. Field guides (Gururaja 2010, Singh 2011, Subramanian 2009, Kiran and David 2013, Grimmett et al. 2011) were used for in situ identification of species, and high-resolution photos (with Canon $600 \mathrm{D}$ camera with Tamron 90 mm macro and Canon 55-250 zoom lenses) were taken for confirmation of the identification. 
Table 1

Name, total area (ha), location, distance (meters) of the studied sacred (in italics), and non-sacred swamps

\begin{tabular}{|lllll|}
\hline Name & Area & Latitude & Longitude & $\begin{array}{l}\text { Average distance to road, settlement or } \\
\text { orchard }\end{array}$ \\
\hline Chaare & 0.18 & $14.408 \mathrm{~N}$ & $74.736 \mathrm{E}$ & 98 \\
\hline Birlakaanu Kudgund & 0.73 & $14.293 \mathrm{~N}$ & $74.758 \mathrm{E}$ & 120 \\
\hline Bogarimakki & 0.90 & $14.387 \mathrm{~N}$ & $74.770 \mathrm{E}$ & 98 \\
\hline $\begin{array}{l}\text { Jaddikodlu } \\
\text { Kudegodu }\end{array}$ & 1.03 & $14.392 \mathrm{~N}$ & $74.754 \mathrm{E}$ & 138 \\
\hline Keremoole & 0.41 & $14.275 \mathrm{~N}$ & $74.771 \mathrm{E}$ & 78 \\
\hline Korse Chapparmane & 0.89 & $14.389 \mathrm{~N}$ & $74.757 \mathrm{E}$ & 138 \\
\hline Kudegodu Devikanu & 0.81 & $14.326 \mathrm{~N}$ & $74.688 \mathrm{E}$ & 94 \\
\hline Mavingadde & 0.48 & $14.392 \mathrm{~N}$ & $74.695 \mathrm{E}$ & 103 \\
\hline Nilkund Chowdikanu & 0.27 & $14.449 \mathrm{~N}$ & $74.704 \mathrm{E}$ & 103 \\
\hline Venkatesh Teertha & 0.40 & $14.547 \mathrm{~N}$ & $74.703 \mathrm{E}$ & 120 \\
\hline Balehaklu & 0.18 & $14.416 \mathrm{~N}$ & $74.754 \mathrm{E}$ & 388 \\
\hline Honnekombu & 0.24 & $14.393 \mathrm{~N}$ & $74.756 \mathrm{E}$ & 363 \\
\hline Hukli & 0.73 & $14.293 \mathrm{~N}$ & $74.788 \mathrm{E}$ & 375 \\
\hline Mundgetaggu & 0.10 & $14.274 \mathrm{~N}$ & $74.773 \mathrm{E}$ & 232 \\
\hline Nandisaalu & 0.90 & $14.269 \mathrm{~N}$ & $74.803 \mathrm{E}$ & 318 \\
\hline Nettikai & 1.03 & $14.416 \mathrm{~N}$ & $74.753 \mathrm{E}$ & 376 \\
\hline Sashikodlu & 0.41 & $14.326 \mathrm{~N}$ & $74.692 \mathrm{E}$ & 433 \\
\hline Shingumane & 0.89 & $14.311 \mathrm{~N}$ & $74.732 \mathrm{E}$ & 318 \\
\hline Sodlekodlu & 0.81 & $14.323 \mathrm{~N}$ & $74.688 \mathrm{E}$ & 292 \\
\hline Somankuli & 0.48 & $14.270 \mathrm{~N}$ & $74.733 \mathrm{E}$ & 232 \\
\hline Bomass productity $(\mathrm{stem}$ & & & & \\
\hline
\end{tabular}

Biomass productivity (stem density and basal area), frequency and importance value index (IVI) of tree species were calculated according to Bonham (2013).

Frequency is the number of times a plant species is present in a given number of quadrats of a particular size or at a given number of sample points. Frequency is usually expressed as a percentage.

Density is an expression of numerical strength of a species in a community. It is calculated as: 


\section{Total number of individuals of all species}

Density $=$

\section{Total area/quadrats sampled}

The basal area of a stand is the total stem area at breast height of all trees in a plot divided by the total area of that plot (Cain 1959; Chaturvedi and Khanna, 1994):

Basal Area $\left(\mathrm{m}^{2}\right)=\mathrm{pi} *(\mathrm{DBH} \text { in } \mathrm{cm})^{2} / 40000$

The Family Importance Value (FIV) for growing stock (volume of all trees $\geq \mathrm{cm} \mathrm{DBH}$ ) was calculated as follows;

FIV = Relative density + Relative diversity + Relative dominance

Where,

Relative density $=$ (Number of individuals in family A / Total number of individuals of all families) $\times 100$

Relative diversity $=$ (Number of species in family A/ Total number of species) $\times 100$

Relative dominance $=($ Basal area of all individuals of family A $/$ Total Basal area of all individuals of all families) $\times 100$

To express both richness (total number of different species) and abundance or evenness (how equally the individuals from each species are represented) into a single numerical value, we used the Shannon $\left(H^{\prime}\right)$ and Simpson (D) diversity indices. The Shannon index is expressed as:

$$
\mathrm{H}^{\prime}=\underset{\mathrm{i}=1}{\left.\stackrel{\mathrm{s}}{\sum}[(\mathrm{ni} / \mathrm{N}) \ln (\mathrm{ni} / \mathrm{N})]\right]}
$$

Where, $\mathrm{ni}=$ the number of individuals belonging to ' $\mathrm{i}^{\text {'th }}$ species;

$\mathrm{N}=$ the total number of individuals in the sample;

$S=$ the number of species

The Simpson (D) index is expressed as:

$$
\mathrm{D}=\sum_{\mathrm{li}=1}^{\mathrm{n}} \mathrm{pi}^{2}
$$

$\mathrm{pi}=$ the proportion of individuals in the $\mathrm{i}^{\text {th }}$ species $=\mathrm{ni} / \mathrm{N}$ 
$P i=n i / N$, where, ni is the number of individuals belonging to the $\mathrm{i}^{\text {th }}$ species and $\mathrm{N}$ is the total number of individuals in the sample.

The value of the Simpson index varies between 0 and 1. As D increases, diversity decreases (Simpson 1949).

To record the regenerating species, two plots (quadrates) of $5 \times 5 \mathrm{~m}$ were laid out; one at the $50^{\text {th }}$ and another at the $100^{\text {th }}$ meter of each transect of varying length along the river. Trees (seedlings) with less than $30 \mathrm{~cm}$ DBH were considered as the regenerating potential of the species. The natural regenerates were grouped into following regeneration classes for further analysis (Puttaswamy et al. 2010):

$0-30 \mathrm{~cm}$ height-_-_-_-_-_ass I

$31-60 \mathrm{~cm}$ height-_-___-_-_Class II

$61-90 \mathrm{~cm}$ height and $<10 \mathrm{~cm}$ GBH (Girth at Breast Height) --_Class III

$91-120 \mathrm{~cm}$ height and 10-30cm GBH---Class IV

The population structure was described as the number of individuals of each tree species in the different diameter classes. The species richness refers to the number of different species represented in a sample (Magurran 1998). Evenness (E) was calculated following Pielou (1996) as:

$E=H^{\prime} / \ln (S)$

Where, $\mathrm{H}^{\prime}=$ Shannon's index

$S=$ Species richness

\section{Results}

In the sacred swamps 122 species from 99 genera and 58 families were found against 83 species from 72 genera and 47 families in the non-sacred swamps (Fig. 1, Fig. 2, Table 2). Lauraceae, Apocynaceae, Anacardiaceae, Moraceae, Myristicaceae and Rubiaceae were the most species-rich families in the sacred swamps, whereas in the non-sacred swamps Euphorbiaceae, Anacardiaceae, Arecaceae, Apocynaceae, Celastraceae, Dipterocarpaceae, Lauraceae and Myristicaceae. 
Table 2

Plant functional types, IUCN Red List species, and total numbers of plant species, genera and families in the total studied area of sacred (1.70 ha) and non-sacred (1.71 ha) swamps.

\begin{tabular}{|c|c|c|c|}
\hline \multicolumn{2}{|l|}{ Plant functional types } & Sacred swamps & Non sacred swamps \\
\hline \multicolumn{2}{|l|}{ Climber species } & 5 & 4 \\
\hline \multicolumn{2}{|l|}{ Epiphyte species } & 1 & 1 \\
\hline \multicolumn{2}{|l|}{ Fern species } & 6 & 2 \\
\hline \multicolumn{2}{|l|}{ Herb species } & 7 & 7 \\
\hline \multicolumn{2}{|l|}{ Liana species } & 8 & 3 \\
\hline \multicolumn{2}{|l|}{ Shrub species } & 14 & 12 \\
\hline \multicolumn{2}{|l|}{ Tree (excl. palm) species } & 74 & 49 \\
\hline \multicolumn{2}{|l|}{ Palm species } & 4 & 5 \\
\hline \multirow[t]{2}{*}{ Status in IUCN Red List* } & Vulnerable species & 8 & 9 \\
\hline & Endangered species & 4 & 3 \\
\hline \multicolumn{2}{|l|}{ Total species } & 122 & 83 \\
\hline \multicolumn{2}{|l|}{ Total genera } & 99 & 72 \\
\hline \multicolumn{2}{|l|}{ Total families } & 58 & 47 \\
\hline
\end{tabular}

Table 3

Diversity, stand density and basal area of trees in the total studied area of sacred (1.70 ha) and non-sacred (1.71 ha) swamps

\begin{tabular}{|lll|}
\hline Properties & Sacred swamp & Non-sacred swamp \\
\hline No. of individuals $>30 \mathrm{~cm} \mathrm{DBH}$ & 437 & 215 \\
\hline Simpson index & 0.579 & 0.615 \\
\hline Shannon index & 1.312 & 1.377 \\
\hline Species richness & 2.78 & 3.61 \\
\hline Evenness index & 0.73 & 0.83 \\
\hline Frequency & 16.3 & 13.66 \\
\hline Stem density (individuals/ha) & 277 & 158.4 \\
\hline Average basal area $\left(\mathrm{m}^{2} / \mathrm{ha}\right)$ & 47.57 & 14.60 \\
\hline
\end{tabular}


Myristicaceae have the highest Family Importance Value both in the sacred $(99.14 \%)$ and in the nonsacred swamps (61.2). Other important families are the Anacardiaceae (26.16\%) and the Celastraceae $(20.54 \%)$ in the sacred, and the Arecaceae (45.6\%) in the non-sacred swamps (Figs. 3 and 4).

Most trees with a GBH > $30 \mathrm{~cm}$ fall in the $30-60 \mathrm{~cm}$ category both in the sacred $(68.4 \%)$ and in the sacred swamp swamps (51.8\%, Fig. 5). $28 \%$ of the plant species are endemic to the Western Ghats in the sacred against $23 \%$ in the non-sacred swamps (annex 1 ).

Table 4

Occurrence of amphibian, bird, butterfly and odonata species in the studied sacred and nonsacred swamps.

\begin{tabular}{|lllll|}
\hline Species & \multicolumn{2}{l}{ Number of species } & \multicolumn{2}{l|}{ Number of individuals } \\
\hline & Sacred swamp & Non sacred swamp & Sacred swamp & Non sacred swamp \\
\hline Amphibian & 25 & 21 & 182 & 119 \\
\hline Birds & 26 & 15 & 44 & 18 \\
\hline Butterflies & 16 & 15 & 27 & 35 \\
\hline Odonata & 15 & 15 & 63 & 57 \\
\hline
\end{tabular}

Number of species and individuals from amphibian, birds, butterflies and odonata are found to be higher in the sacred swamps compared to the non-sacred swamps (Table 4).

The Simpson index for all fauna was 0.40 in the sacred and 0.36 in the non-sacred swamps, whereas the Shannon index was -1.1 and -1.2 , respectively.

Three critically endangered amphibian species from the IUCN Red List, Nyctibatrachus dattatreyaensis, Pseudophilautus amboli and Micrixalus kottigeharensis, were found to occur in both sacred and nonsacred swamps, however, non-sacred swamps were represented by only 6 individuals where as it was 22 individuals in sacred swamps. (Table 5). 
Table 5

Occurrence of threatened species of amphibians according to the IUCN Red List in the studied sacred (1.70 ha) and non-sacred swamp transects (1.71 ha). See for details appendix 2.

\begin{tabular}{|lllll|}
\hline IUCN & Sacred swamps & Non sacred swamps \\
\hline $\begin{array}{l}\text { Category } \\
\text { Number of } \\
\text { species }\end{array}$ & $\begin{array}{l}\text { Number of } \\
\text { individually }\end{array}$ & $\begin{array}{l}\text { Number of } \\
\text { species }\end{array}$ & $\begin{array}{l}\text { Number of } \\
\text { individuals }\end{array}$ \\
\hline Endangered & 3 & 22 & 3 & 6 \\
\hline Vulnerable & 1 & 56 & 2 & 8 \\
\hline Near threatened & 2 & 1 & 0 & 0 \\
\hline
\end{tabular}

\section{Discussion}

Consistently more species ( 122 species with 58 plant families) were found to occur in the sacred compared to the non-sacred swamps (87 species and 47 families). Higher species numbers have also been recorded in sacred compared to non-sacred non-swamp sites in the south-eastern coastal belt of India near Pondicherry (Ramanujan and Kadamaban 2001).

Although the number of plant species in the swamps is low compared to well-watered (but not waterlogged) land, the occurring species are often site or habitat specific and endemic and contribute significantly to the regional biodiversity of the Western Ghats (Chandran et al. 1999; Chandran and Mesta 2001; Roby and Nair 2006).

The basal area of tree species in the sacred swamps was much higher $\left(47.57 \mathrm{~m}^{2} / \mathrm{ha}\right)$ compared to that in the non-sacred swamps $\left(14.6 \mathrm{~m}^{2} / \mathrm{ha}\right)$. A high basal area indicates the presence of old and huge trees. The highest basal area in sacred forests in the Kakachi forests was reported to be $42.03 \mathrm{~m}^{2} / \mathrm{ha}$ (Ganesh et al. 1996) and $47.01 \mathrm{~m}^{2} /$ ha for the Uppinangala forest (Pascal and Pelissier 1996).

The average density of trees above $30 \mathrm{~cm} \mathrm{GBH}$ in the (natural) forests of the Western Ghats ranged from 446 to 1576 stems/ha (Ganesh et al. 1996; Ayyappan and Parthasarathy 1999, Parthasarathy 2001). Sukumaran (2008) recorded a stem density of 100 / ha in the sacred groves of Astheeshwaram of Southern peninsular India, whereas in our study the density in sacred and non-sacred swamps was 277 and 156 stems per hectare, respectively. The rather small biomass productivity (stem density and basal area) in our samples could be due to the constant water level throughout the year. Conner (1976) and Brinson et al. (1981) found that seasonally flooded open systems are generally more productive than stagnant closed ones. Productivity was approximately double in wetlands subject to periodic flooding, compared to stagnant or slowly flowing systems (Mitsch 1991). Further, area of both sacred and nonsacred swamps was small compared to other studies, which are in the terrestrial ecosystems. 
In the study sites, tree cutting intensity was high in the non - sacred swamps, which is evident from the presence of cut stumps and cutting of knee roots of Gymnacranthera canarica. We did not find evidence of cutting in the sacred swamps. The cultivated species Musa paradisiaca and Areca catechu were found only in non-sacred swamps, indicating attempts to convert them into commercial orchards.

Sacred swamps had $28 \%$ of endemic species while non-sacred swamps had $23 \%$. Vasanthraj and Chandrashekhar (2006) reported that $37 \%$ of the species from Charmady reserve forest are endemics of the Western Ghats, whereas the average endemism for evergreen forests of the Western Ghats is around $41 \%$ (Ghate et al. 1998).

Only few species, i.e. Myristica fatua var. magnifica and Gymnacranthera canarica, can survive in the depression part of the swamp forests with permanently water-logged conditions because their stilt and aerial roots provide anchoring and breathing capacity. These species along with facultative swamp species like Vateria indica, Dipterocarpus indicus, Dysoxylum binecteriferum, Myristica malabarica, Mastixia arborea, Lophopetalum wightianum and Calophyllum apetalum (Annex 1) are very old in origin ('palaeoendemics' - relic plants with ancient pedigree) and indicator species of evergreen climax forests, and important shelter and food plants for rare and endangered species like lion tailed macaque (Macaca silenus, Ramachandran and Joseph 2000) and great pied hornbill (Buceros biornis), (Ali et al. 2006).

The interaction between forest disturbance, regeneration and succession determines the size and age distribution of trees (Kuuluvainen et al. 1996). Biological quality ('health') of forests is often indicated by their size class distribution and regeneration ability, with a large proportion of seedlings and saplings reflecting a growing population (Murali et al. 1996). With regard to diameter classes, the sacred swamps show a clear 'reverse $J$ ' shape distribution curve, in contrast to the non-sacred swamps, which show a much lower prevalence of the lowest (Fig. 6) and the complete absence of trees in the highest girth classes (Fig. 5).

Amphibian assemblages are good indicators of environmental health (Hager 1998, Gibbs 1998) as amphibians are sensitive to environmental change (Blaustein 1994, Pearman 1997, Daniels 1999). In our study, sacred swamps have a higher number of amphibian species and a higher number of threatened species when compared to non-sacred swamps. Diversity and richness of bird, butterfly and odonata species were, however, only marginally higher in the sacred swamps. Higher species richness and composition in non-sacred swamp is an effect of mild disturbance that favours the early invaders and the deciduous species essentially increases the species richness. However, the studies of Murali and Setty (2001) have observed high species richness as well as forest stand in the plots with mild disturbance than the less disturbed plots. Methachen (2002) reported that the disturbed evergreen forests of Uttara Kannada district were floristically more rich compared to undisturbed evergreen forest in terms of species richness as well as diversity indices complying to the 'mild disturbance' theory.

\section{Conclusions}


Our study shows that the species composition and diversity patterns - tree population, stem density, and the basal area of tree species - are higher in sacred swamps compared to non-sacred swamps.

Regeneration of swampy species is much better in sacred swamps. Both natural and human activities have an effect on species diversity, population structure, and natural regeneration of a forest ecosystem. Vegetation characteristics make it clear that sacred swamps act as safe zones for the in-situ conservation of many endemic and red listed species of the Western Ghats. This condition is made possible, only because the local community restricts anthropogenic activities. This social fencing, i.e. the most viable form of protection in the field, is based on traditional values of local communities, evolved over long time. Such community behaviour requires a socio-cultural ecosystem to nourish it and local forest dwelling communities must be given credit for ensuring survival of these biodiverse habitats. We conclude that the traditional practices of protecting the swamp forests play an important role in biodiversity conservation.

\section{Declarations}

\section{Acknowledgements}

We thank Suhas and Medha for assisting in identifying amphibians, butterflies and bird species identification. We thank Almut Mrotzek, Rajesh Gunaga, Chiara, Rafael Zeigler and anonymous reviewers for their constructive comments.

\section{References}

1. Ali S, Chandran MS, Ramachandra TV (2006) Faunal assemblages in Myristica swamps of central Western Ghats, Karnataka, India. In Proceedings of the Symposium on Environment Education \& Ecosystem Conservation. Indian Institute of Science, Bangalore

2. Ayyappan N, Parthasarathy N (1999) Biodiversity inventory of trees in a large-scale permanent plot of tropical evergreen forest at Varagalaiar, Anamalais, Western Ghats, India. Biodiversity Conservation 8(11):1533-1554

3. Bawa KS, Das A, Krishnaswamy J, Karanth U, Sambakumar N (2007) Ecosystem profile: Western Ghats \& Sri Lanka biodiversity hotspot-Western Ghats region. Critical Ecosystem Partnership Fund

4. Blaustein AR, Wake DB, Sousa WP (1994) Amphibian declines: judging stability, persistence, and susceptibility of populations to local and global extinctions. Conserv Biol 8(1):60-71

5. Bonham CD (2013) Measurements for terrestrial vegetation. John Wiley \& Sons; New York (2013)

6. Byers BA, Cunliffe RN, Hudak AT (2001) Linking the conservation of culture and nature: a case study of sacred forests in Zimbabwe. Human Ecology 29(2):187-218

7. Brinson MM (1981) Riparian ecosystems: their ecology and status. Eastern Energy Land Use Team [and] National Water Resources Analysis Group, US Fish and Wildlife Service 
8. Begon M, Harper JL, Townsend CR (1986) Ecology. Individuals, populations and communities. Blackwell scientific publications

9. Cain SA, Castro GM (1959) Manual of Vegetation analysis. Harper, NY pp 325

10. Campbell MO (2004) Traditional forest protection and woodlots in the coastal savannah of Ghana. Environ Conserv 31(3):225-232

11. Ceperley N, Montagnini F, Natta A (2010) Significance of sacred sites for riparian forest conservation in Central Benin. Bois et Fore^ts des Tropiques 303(1):5-23

12. Chandran MDS, Mesta DK, Naik MB (1999) Inventorying and conservation of the Myristica swamps of Uttara Kannada. Report of Research and Training Institute, Bangalore

13. Chandran MDS, Mesta DK (2001) On the conservation of the Myristica swamps of the Western Ghats. Forest genetic resources: status, threats, and conservation strategies, 1-19

14. Chaturvedi AN, Khanna LS, Forest Mensuration (1994) International Book Distributors, Dehradun, India. pp 406

15. Conner WH, Day JW Jr (1976) Productivity and composition of a baldcypress-water tupelo site and a bottomland hardwood site in a Louisiana swamp. Am J Bot 63(10):1354-1364

16. Cooke T (1903) The flora of the Presidency of Bombay. Taylor and Francis, London

17. Daniels RJR, Gadgil M, Joshi NV (1995) Impact of human extraction on tropical humid forests in the Western Ghats in Uttara Kannada, South India. J Appl Ecol 32:866-874

18. Gadgil M, Chandran MS (1992) Sacred groves. India International Centre Quarterly 19(1/2):183-187

19. Gadgil M, Vartak VD (1976) Sacred groves in Western Ghats in India. Econ Bot 30:152-160

20. Gamble JS, Fischer CEC (1935) Flora of Presidency of Madras, vol 1-3. Adlard and Son, London

21. Ganesh T, Ganesan R, Soubadradevi M, Davidar P, Bawa KS (1996) Assessment of plant biodiversity at mid-elevation evergreen forest of Kalakad- Mundanthurai Tiger Reserve, Western Ghats, India. Curr Sci 71(5):379-392

22. Ghate U, Joshi NV, Gadgil M (1998) On the patterns of tree diversity in the Western Ghats of India. Current science 75(6):594-603

23. Gibbs JP (1998) Amphibian movements in response to forest edges, roads, and streambeds in southern New England. J Wildl Manag 62:584-589

24. Giriraj A, Murthy MSR, Ramesh BR (2008) Vegetation Composition, Structure and Patterns of Diversity: A Case Study from the Tropical Wet Evergreen Forests of the Western Ghats, India. Edinburgh Journal of Botany 65:1-22. doi:10.1017/S0960428608004952

25. Grimmett R. Inskipp C, Inskipp T (2011) Birds of Indian subcontinent. Oxford university press, New Delhi

26. Gupta N, Anthwal A, Bahuguna A (2006) Biodiversity of Mothronwala Swamp, Doon valley, Uttaranchal. The J of American Science 2(3):33-40

27. Gururaj KV (2012) Pictorial Guide to Frogs and Toads of Western Ghats. Gubbi labs, Bangalore 
28. Hager HA (1998) Area-sensitivity of reptiles and amphibians: Are there indicator species for habitat fragmentation? Ecoscience 5(2):139-147

29. Hansen AJ, Spies TA, Swanson FJ, Ohmann JL (1991) Conserving biodiversity in managed forests. Bioscience 41(6):382-392

30. Hegde N, Ziegler R, Greiser C, Joosten H (2018) A preliminary assessment of landscape features and cultural practices of sacred fresh water swamps in the central Western Ghats, India. Wetlands Ecology Management: 26(1):49-61

31. Kiran CG, Raju DV (2013) Dragonflies and Damselflies of Kerala. Keralathile thumbikal. Tropical Institute of Ecological Science, p 156

32. Komanda B, Angu AK, Ngui Nguiri JC (2003) The social value of the Nyangkpe sacred forests. In: Eds: Harmon D, Putney AD The full value of the parks: from economics to the intangible. Rowman and Littlefield Publishers, Inc. Lanham

33. Kuuluvainen T, Penttinen A, Leinonen K, Nygren M (1996) Statistical opportunities for comparing stand structural heterogeneity in managed and primeval forests: an example from boreal spruce forest in southern Finland. Silva Fennica 30(2-3):315-328

34. Leigh EG (1965) On the relation between the productivity, biomass, diversity, and stability of a community. Proceedings of the National Academy of Sciences, 53(4), pp777-783

35. MacArthur RH (1965) Patterns of species diversity. Biological reviews 40(4):pp510-533

36. MacArthur RH, MacArthur JW (1961) On bird species diversity. Ecology 42(3):594-598

37. Magurran AE (1988) Ecological diversity and its measurement. Princeton university press, New Jersy, pp 1-179

38. Methachen GP (2002) Assessment of Ecological Amplitude of Artocarpus hirsutus Lam.: A Threatened Multipurpose Tree. M. Sc. Thesis submitted to University of Agricultural Sciences, Dharwad, p. 91

39. Mitsch WJ, Taylor JR, Benson KB (1991) Estimating primary productivity of forested wetland communities in different hydrologic landscapes. Landscape Ecol 5(2):pp75-92

40. Murali KS, Siddappa Setty R (2001) Effect of weeds Lantana camara and Chromolaena odorata growth on the species diversity, regeneration and stem density of tree and shrub layer in Biligiri Ranganatha Temple Sanctuary. Curr Sci 80:675-676

41. Murali KS, Shankar U, Shaanker RU, Ganeshaiah KN, Bawa KS (1996) Extraction of non-timber forest products in the forests of Biligiri Rangan Hills, India. 2. Impact of NTFP extraction on regeneration, population structure, and species composition. Econ Bot 50(3):252-269

42. Murdoch WW, Evans FC, Peterson CH (1972) Diversity and pattern in plants and insects. Ecology 53(5):819-829

43. Myers N, Mittermeier RA, Mittermeier CG, Da Fonseca GA, Kent J (2000) Biodiversity hotspots for conservation priorities. Nature 403(6772):pp853-858 
44. Noss RF (1990) Indicators for monitoring biodiversity: a hierarchical approach. Conservation biology 4(4):pp355-364

45. Ntiamoa-Baidu Y (2008) Indigenous Beliefs and Biodiversity Conservation: The Effectiveness of Sacred Groves, Taboos and Totems in Ghana for Habitat and Species Conservation. Journal for the Study of Religion, Nature \& Culture, 2(3)

46. Pandey SK, Shukla RP (1999) Gradient in plantation forests of sal (Slzorea robusta Gaertn.). Current Science 77(6)

47. Parthasarathy $N$ (2001) Changes in forest composition and structure in three sites of tropical evergreen forest around Sengaltheri, Western Ghats. Current science, pp 389-393

48. Pascal JP, Pelissier R (1996) Structure and floristic composition of a tropical evergreen forest in south-west India. J Trop Ecol 12:191-214

49. Pascal JP, Ramesh BR (1987) A field key to the trees and lianas of the evergreen forests of the Western Ghats (India). Trav Sect Sci Techn Inst Franc Pondichery 23:1-236

50. Pausas JG, Austin MP (2001) Patterns of plant species richness in relation to different environments: An appraisal. J Veg Sci 12:153-166

51. Pearman PB (1997) Correlates of amphibian diversity in an altered landscape of Amazonian Ecuador. Conservation biology 11(5):1211-1225

52. Pielou EC (1966) Species diversity and pattern diversity in the study of ecological succession. Journal of Thereotical Biology 10:370-383

53. Puttaswamy H, Kushalappa CG, Ajayan KV, Sathish BN (2012) Distribution and population status of a critically endangered tree species Dipterocarpus bourdillonii Brandis in central Western Ghats. In Proceedings of International Forestry Environment Symposium (Vol. 15, pp. 150-154)

54. Ramachandran KK, Joseph GK (2000) Habitat utilization of Lion-Tailed Macaque (Macaca silenus) in Silent Valley National Park, Kerala India. Primate Report.:17-26

55. Ramanujam MP, Kadamban D (2001) Plant biodiversity of two tropical dry evergreen forests in the Pondicherry region of South India and the role of belief systems in their conservation. Biodiv Conserv 10:1203-1217

56. Roby TJ, Nair PV, 2006, Myristica swamps- An endangered ecosystem in the Western Ghats. In: Proc. XVIII Kerala Sci. Cong., India. pp. 386-388

57. Sagar R, Raghubanshi AS, Singh JS (2003) Tree species composition, dispersion and diversity along a disturbance gradient in a dry tropical region of India. Forest Ecology and Management 186 (2003) 61-71. DOI: 10.1016/s0378-1127(03)00235-4

58. Shahabuddin G, Rao M (2010) Do community-conserved areas effectively conserve biological diversity? Global insights and the Indian context. Biol Cons 143:2926-2936.

DOI:10.1016/j.biocon.2010.04.040

59. Shannon CE, Weaver W (1949) The Mathematical Theory of Communication. University of Illinois Press, Urbana 
60. Shen X, Li S, Wang D, Lu Z (2015) Viable contribution of Tibetan sacred mountains in southwestern China to forest conservation. Conserv Biol 29(6):pp1518-1526

61. Simpson EH (1949) Measurement of diversity. Nature 163:688

62. Singh AP (2011) Butterflies of India. Om Books International

63. Singh H, Pande PC, Agnihotri P, Husain T (2011) Biodiversity conservation through a traditional beliefs system in Indian Himalaya: a case study from Nakuleshwar sacred grove. Environmentalist 31:246-253. DOI 10.1007/s10669-011-9329-6

64. Subramanian KA, Gadgil M (2009) Dragonflies of India, a field guide. Vigyan Prasar

65. Sukumaran S, Jeeva S (2008) A floristic study on miniature sacred forests at Agastheeshwaram, southern peninsular India. EurAsian Journal of BioSciences 2:66-72

66. Talbot WA (1909-1911) Forest Flora of Bombay Presidency and Sindh, Government at the Photozincographic department, Poona, India. Vol. I-II

67. Tiwari BK, Barik SK, Tripathi RS (1998) Biodiversity value, status, and strategies for conservation of sacred groves of Meghalaya, India. Ecosystem Health 4(1):20-32

68. Vasanthraj BK, Chandrashekar KR (2006) Analysis of the structure of Charmady reserve forest. Tropical Ecology 47(2):279-290

\section{Figures}

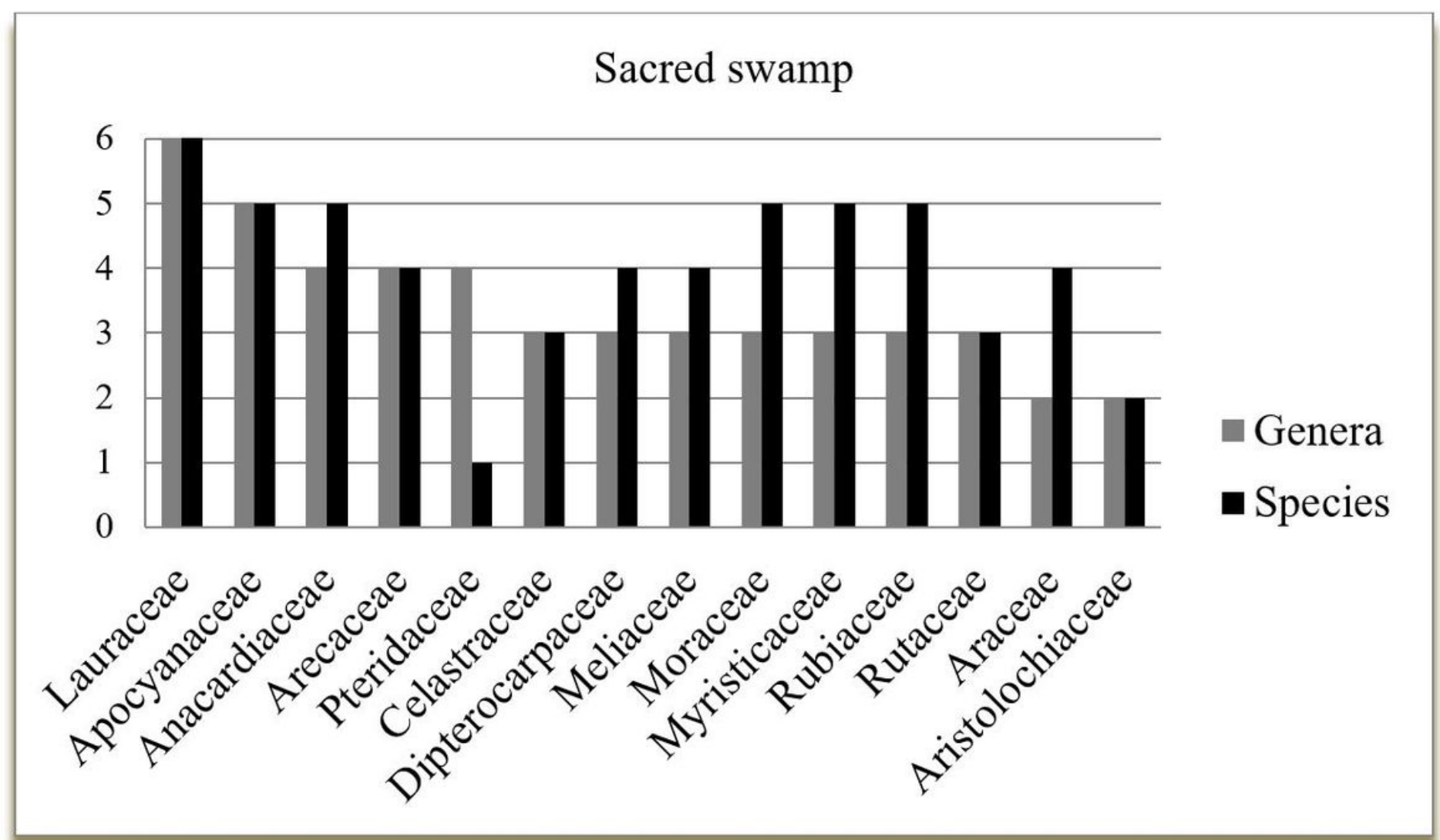


Figure 1

Number of genera and species per family in the studied 1.70 ha of sacred swamps.

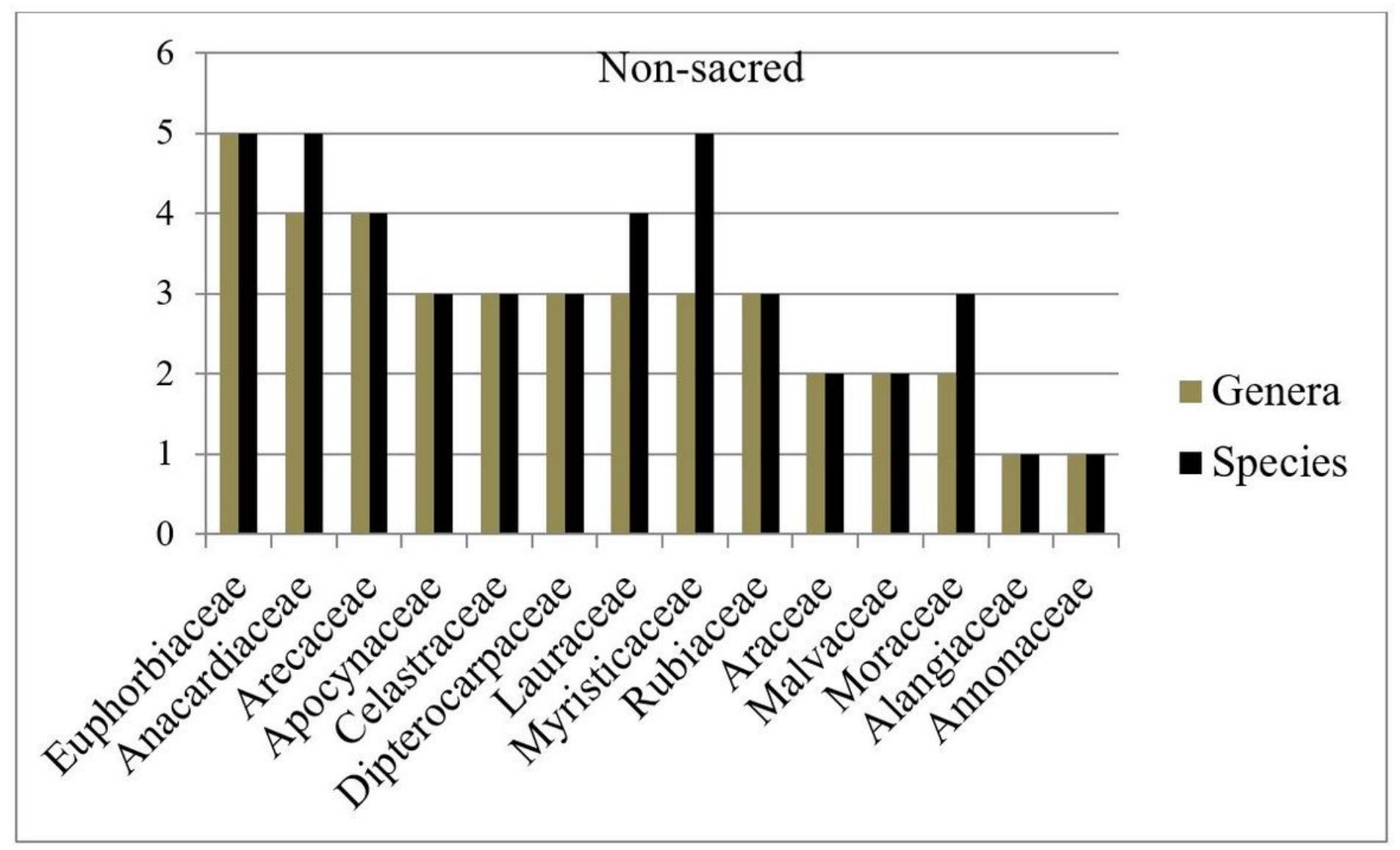

Figure 2

Number of genera and species per family in the studied 1.71 ha of non-sacred swamps 


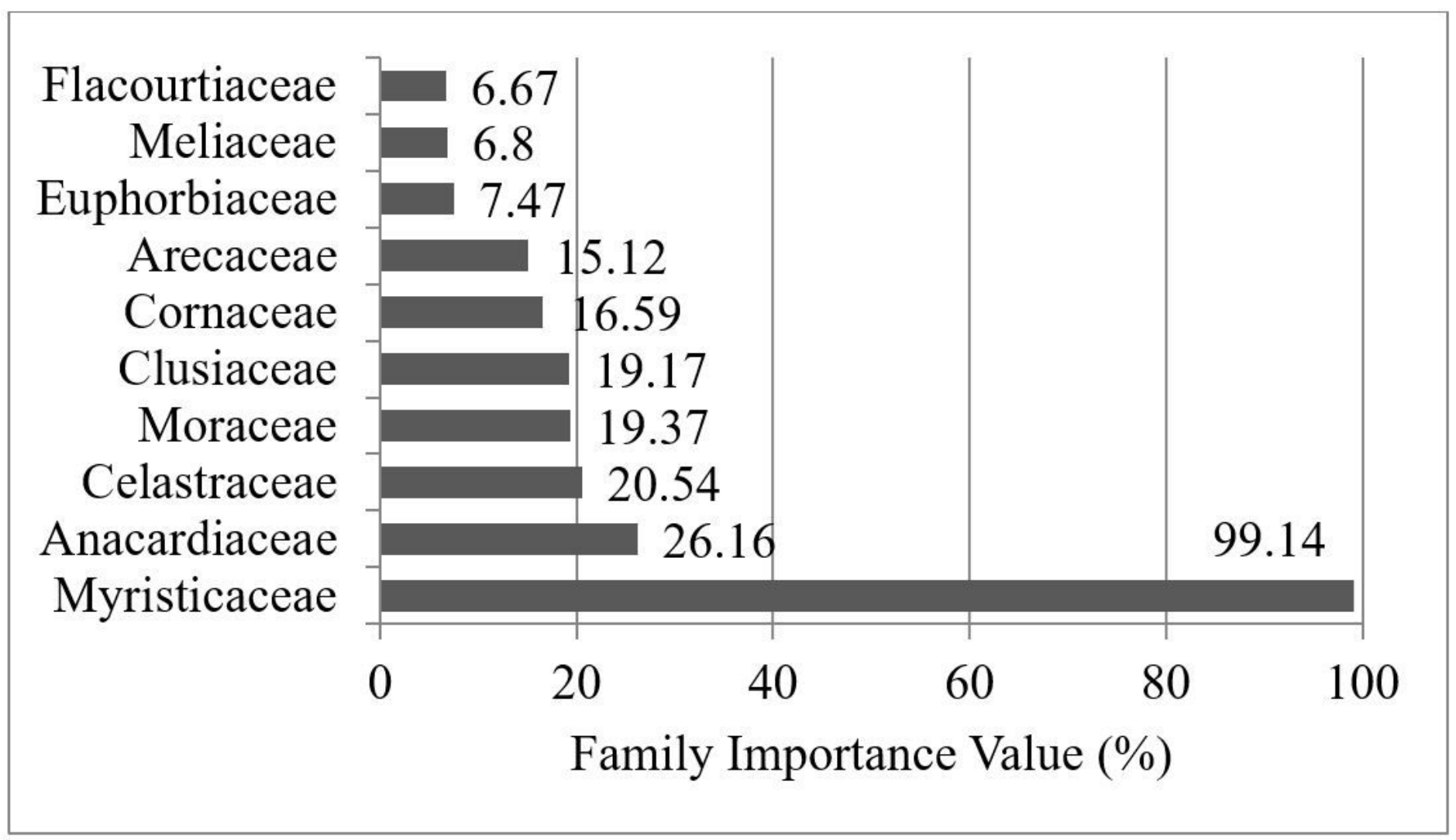

Figure 3

Family Importance Value for the tree species in the studied sacred swamps 


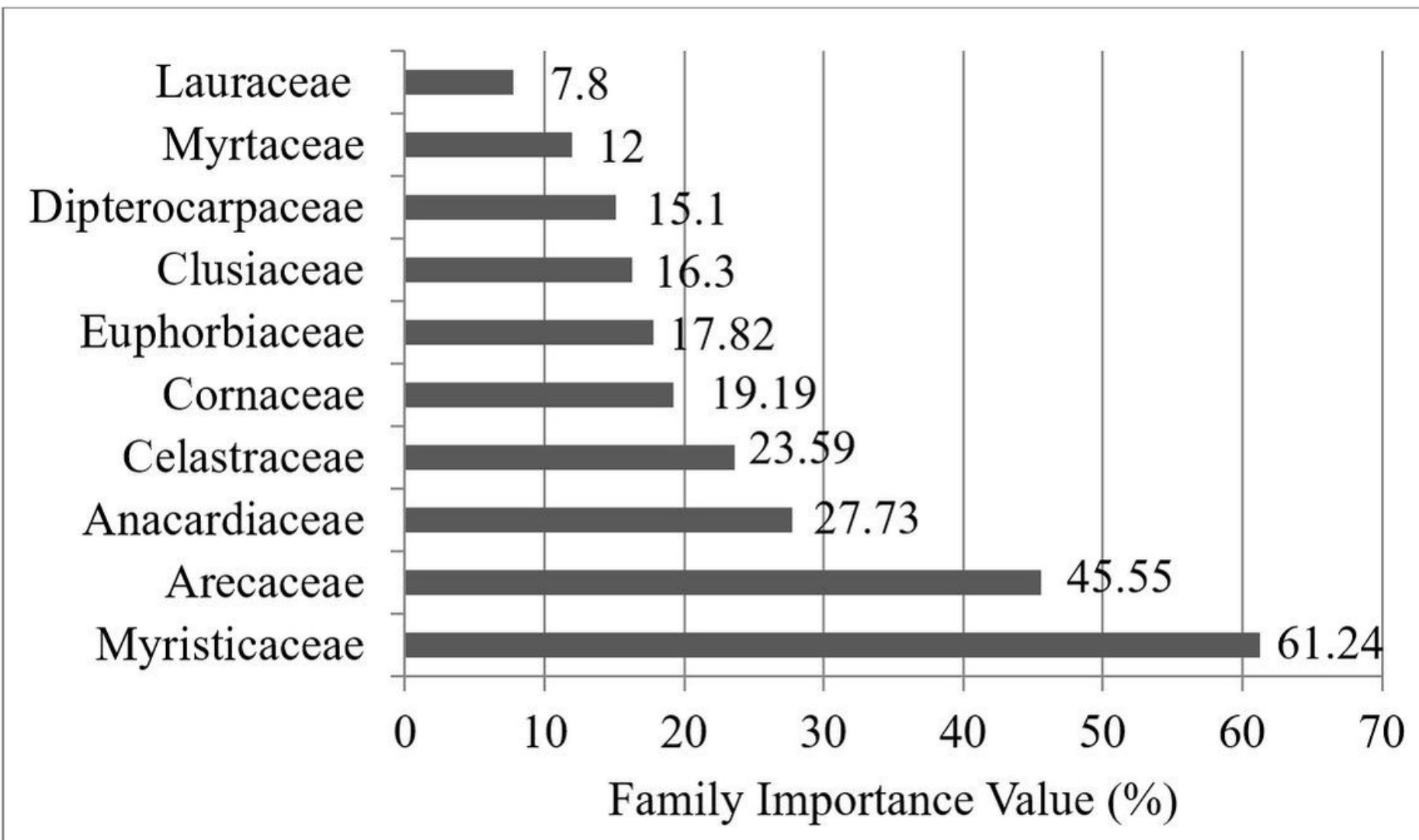

Figure 4

Family Importance Value for the tree species in the studied non-sacred swamps 


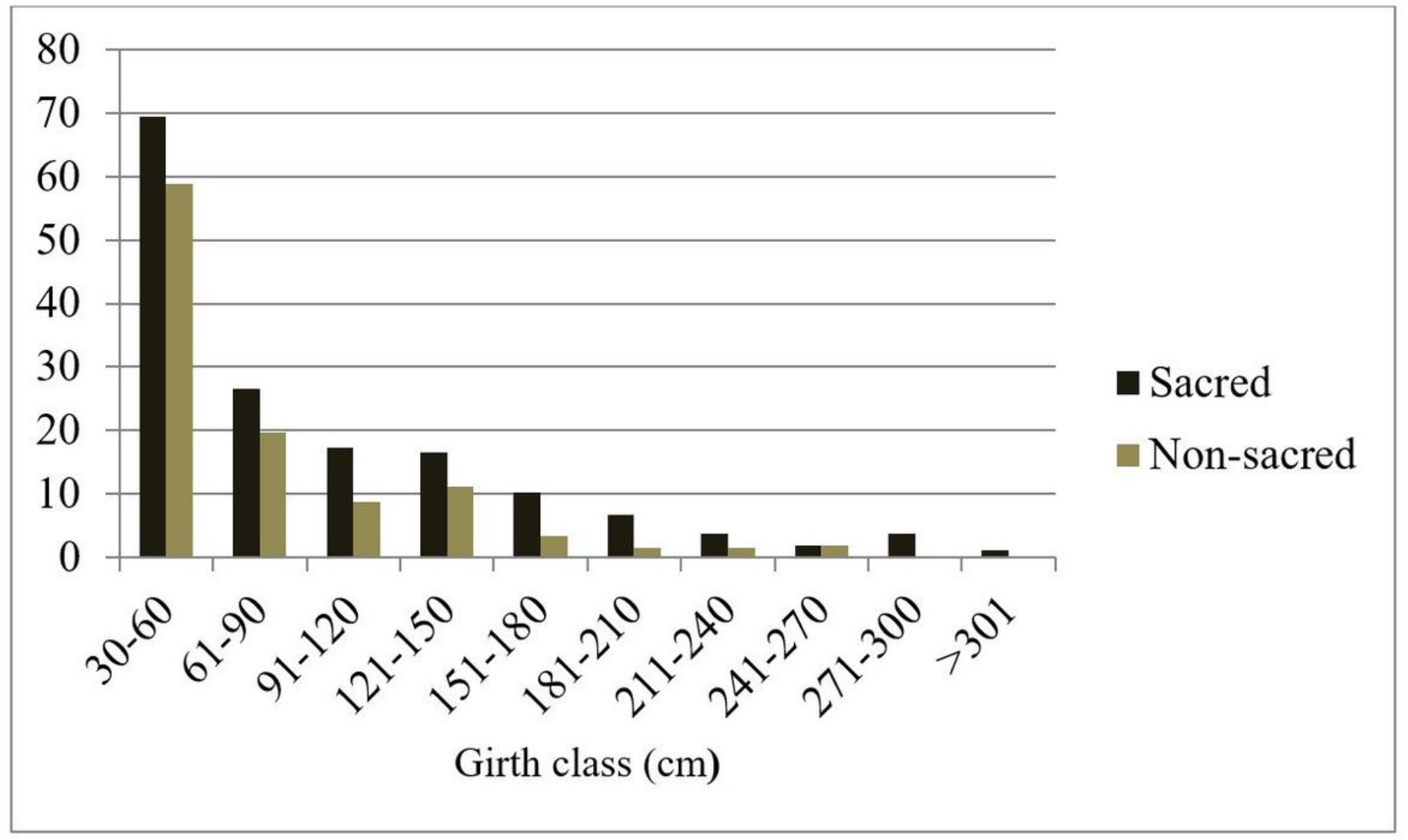

Figure 5

Size class distribution of trees in girth classes $>30 \mathrm{~cm} \mathrm{DBH}$ in the studied sacred and non-sacred swamps
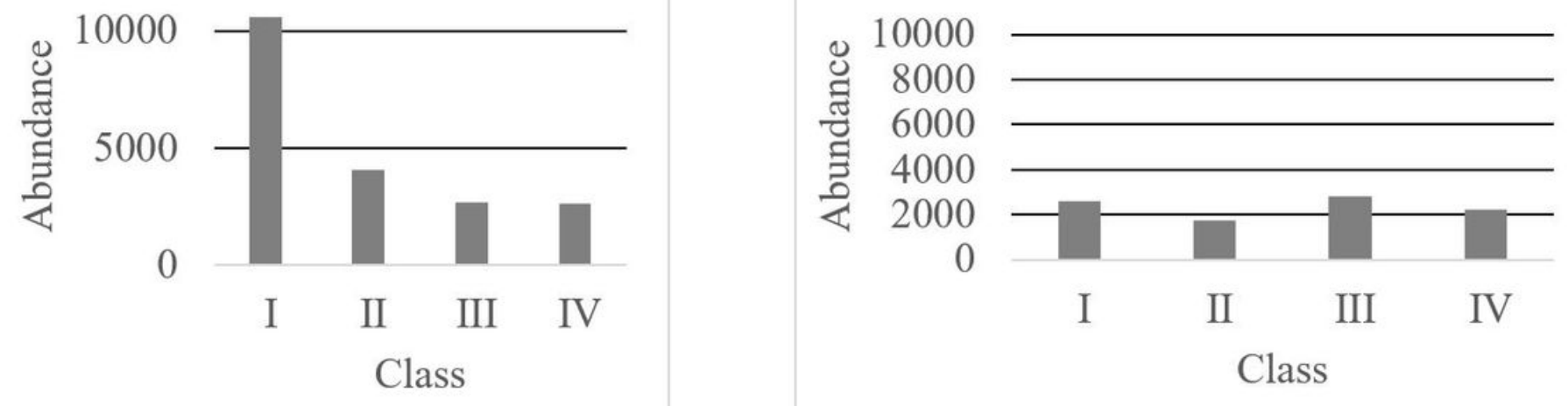

Figure 6

Abundance of regenerated trees $(\mathrm{N})$ in the studied sacred swamp (1.70 ha, left) and non-sacred swamp areas (1.71 ha, right). Class I: $0-30 \mathrm{~cm}$ height, II: $31-60 \mathrm{~cm}$; III: $61-90 \mathrm{~cm}$ height and < $10 \mathrm{~cm} \mathrm{GBH}$, IV: $91-120 \mathrm{~cm}$ height and 10-30cm GBH.

\section{Supplementary Files}


This is a list of supplementary files associated with this preprint. Click to download.

- Annex1Listofplantspecies.docx

- Annex2Listofamphibnianspecies.docx

- Annex3Listofodonataspecies.docx

- Annex4Listofbuterflies.docx

- Annex5Listofbirdspecies.docx

- Fundingsources.docx 